\title{
Osteonecrosis of The Jaw; Medication- Related Osteonecrosis of the Jaw (MRONJ)
}

\author{
Susanti Bulan ${ }^{1}$ \\ ${ }^{1}$ Departemen Ilmu Bedah Mulut, Fakultas Kedokteran Gigi, Universitas Kristen Maranatha \\ susantibulan@gmail.com
}

\begin{abstract}
Abstrak
Sejak tahun 2004, dilaporkan terjadinya osteonecrosis of the jaw pada pasien osteoporosis yang mengonsumsi bifosfonat, walaupun hal tersebut lebih sedikit dibandingkan kejadian osteonecrosis of the jaw pada penderita kanker yang mendapat terapi bifosfonat secara intravena. American Association of Oral and Maxillofacial Surgeons (AAOMSs) pada tahun 2014 menyatakan perubahan nomenklatur Bisphosphonate-Related Osteonecrosis Of The Jaw (BRONJ) menjadi Osteonecrosis of the jaw atau Medication-Related Osteonecrosis of The Jaw (MRONJ) yaitu destruksi tulang progresif di daerah maksilofasial pasien yang disebabkan oleh terapi antiresopsi an antiangiogenik lain. AAOMS melaporkan peningkatan risiko $0,5 \%$ perkembangan MRONJ setelah prosedur ekstraksi gigi pada penderita yang menkonsumsi Bifosfonat (BP) secara oral, dan peningkatan risiko $1,6-14,8 \%$ pada penderita dalam terapi BP secara intra vena. Risiko perkembangan MRONJ terjadi setelah prosedur perawatan gigi seperti ekstraksi gigi, implant gigi, perawatan endodontik, dan perawatan periodontik. Patofisiologi MRONJ tidak sepenuhnya dapat dijelaskanyaituyang berkaitan dengan peradangan atau infeksi, mikrotrauma, perubahan remodeling tulang atau penekanan berlebihan pada resorpsi tulang, penghambatan angiogenesis, toksisitas BP jaringan lunak, biofilm khas rongga mulut, vaskularisasi mandibula, penekanan imunitas, atau defisiensi vitamin D. Pilihan antara perawatan konservatif dan pembedahan tidaklah mudah dan harus disesuaikan dengan kasus. Tujuan utama perawatan MRONJ praktisi dokter gigi dan spesialis bedah mulut dan maksilofasial adalah pengendalian infeksi, perkembangan nekrosis tulang, dan nyeri.Tujuan dari studi pustaka ini adalah untuk menggambarkan pengetahuan terkini tentang MRONJ, pencegahan dan strategi manajemennya.
\end{abstract}

Kata kunci: MRONJ, patofisiologi, staging system, pencegahan dan pengobatan 


\section{Pendahuluan}

Osteonecrosis of the jaw atau MRONJ adalah destruksi tulang progresif di daerah maksilofasial yang terkait dengan terapi antiresorpsi lain (Denosumab) dan terapi antiangiogenik. ${ }^{1}$

\section{Medication- Related Osteonecrosis of the Jaw (MRONJ)}

Osteonekrosis rahang (ONJ) dapat disebabkan oleh dua agen farmakologis, yaitu: antiresorpsi (termasuk BP dan Receptor Activator of Nuclear factor Kappa- (RANK) B ligand inhibitors) dan antiangiogenik. ${ }^{1}$

Bifosfonat dapat dibagi menjadi aminobisphosphonate (BP) dan non-BP (NBP) berdasarkan kehadiran gugus fungsi amino dalam molekul. NBP adalah yang terlibat dalam kasus ONJ. ${ }^{1}$ Bifosfonat intravena (IV) digunakan untuk mengobati kondisi yang terkait dengan kanker serta hiperkalsemia karena malignansi, kejadian terkait skeletal yang berhubungan dengan metastasis tulang dari tumor padat dan untuk manajemen lesi litik yang berhubungan dengan multiple myeloma. Bifosfonat oral digunakan untuk mengobati osteoporosis, osteopenia, atau kondisi lain yang tidak umum seperti Paget's Disease dan Osteogenesis Imperfecta. ${ }^{2}$ Inhibitor ligand RANK (Denosumab) adalah obat antiresorpsi yang menghambat fungsi osteoklas, mengurangi resorpsi tulang, dan meningkatkan kepadatan tulang. Inhibitor ligand RANK digunakan pada pasien yang terkena osteoporosis atau penyakit tulang metastatik. ${ }^{2}$ Obat antiangiogenik menghambat perkembangan pembuluh darah baru, memblokir kaskade pemberian sinyal saat proses angiogenesis. Pada dasarnya obat tersebut dapat dibagi menjadi dua jenis: antibodi monoklonal yang menghentikan reseptor atau faktor pertumbuhan (Bevacizumab) dan molekul kecil, yang menentukan penghalang dengan mengikat reseptor tirosin kinase (Sunitinib dan Sorafenib). ${ }^{3}$

\section{Patofisiologi MRONJ}

Patofisiologi MRONJ tidak sepenuhnya dapat dijelaskan. Ada beberapa hipotesis yang dapat menjelaskan, yaitu peradangan atau infeksi, mikrotrauma, perubahan remodeling tulang atau penekanan berlebihan pada resorpsi tulang, penghambatan angiogenesis, toksisitas BP jaringan lunak, biofilm khas rongga mulut, vaskularisasi terminal dari mandibula, penekanan imunitas, atau defisiensi vitamin D. ${ }^{4}$

Tiga faktor risiko seperti faktor lokal, penyakit primer, dan jenis obat harus dipertimbangkan sebagai patofisiologi dan insidensi MRONJ. Kita harus mempertimbangkan dua kriteria, yaitu indikasi terapeutik (osteoporosis/osteopenia dan keganasan/malignansi) dan jenis obat (BP dan non-BP (NBP). ${ }^{4}$

Bedah mulut adalah salah satu faktor risiko terbesar terjadinya MRONJ. Menurut beberapa penulis, 52-61\% pasien melaporkan pencabutan gigi sebagai peristiwa pencetus terjadinya MRONJ. Risiko MRONJ pada pasien yang diobati dengan BP oral setelah pencabutan gigi adalah $0,5 \%$; risiko ONJ pada pasien dengan kanker yang diobati dengan BP secara intra vena (iv) berkisar antara 1,6\% hingga 14,8\%. MRONJ muncul lebih sering pada mandibula $(73 \%)$ dibandingkan maksila $(22,5 \%)$; sementara kasus yang melibatkan kedua rahang adalah $4,5 \%$ dari kasus. ${ }^{5}$

\section{Definisi dan Sistem Stadium Klinis (Staging System) MRONJ}

Manifestasi klinis pasien yang mengalami MRONJ:

1. Sedang dalam perawatan yang atau pernah dilakukan perawatan terdahulu dengan obat antiangiogenik atau antiresorptif 
2. Pasien tidak memiliki riwayat terapi radiasi atau manifestasi metastasis pada rahang

3. Tulang yang terpapar atau adanya fistula intraoral atau ekstraoral di daerah maksilofasial yang bertahan selama lebih dari 8 (delapan) minggu. ${ }^{6}$

Pada tahun 2012, SICMF (Italian Society for Maxillofacial Surgery) dan SIPMO (Italian Society of Oral Pathology and Medicine) mengusulkan definisi baru: "BRONJ yang merupakan reaksi obat merugikan dan digambarkan sebagai perusakan progresif dan kematian tulang yang memengaruhi mandibula atau maksila pasien yang terpapar pengobatan BP yang mengandung nitrogen, tanpa adanya pengobatan radiasi sebelumnya". Hal tersebut didukung oleh penelitian sejumlah besar pasien di Eropa. Menurut definisi AAOMS, hanya $76 \%$ dari BRONJ yang dapat terdiagnosis; $24 \%$ sisanya tidak dapat didiagnosis karena tidak ditemukan adanya tulang yang nekrotik. Stadium klinis BRONJ sangat banyak dan sebagian besar didasarkan pada gambaran klinis. Pada tahun 2006, Ruggiero et al. mengusulkan stadium klinis berdasarkan tanda dan gejala klinis; pada tahun 2009, AAOMS mengimplementasikannya dengan tahap-tahap seperti pada tabel 1 .Pada tahun 2007, Marx adalah satu-satunya yang membagi stadium klinis berdasarkan ukuran lesi. Bedogni et al., pada tahun 2012, mengusulkan stadium klinis BRONJ dapat dilihat pada Tabel $1 .^{7}$

Tabel 1-Stadium Klinis Osteonekrosis Terkait Bisfosfonat pada Rahang ${ }^{7}$ 


\begin{tabular}{|c|c|c|c|}
\hline Tingkatan & Marx 2007 & AAOMS 2009 & SICMF - SOPMO 2012 \\
\hline Kategori beresiko & & $\begin{array}{l}\text { Tidak terdapat bukti yang } \\
\text { terlihat atau tulang nekrotik } \\
\text { pada pasien yang diberi } \\
\text { pegobatan bifosfonat }\end{array}$ & \\
\hline Tingkat 0 & $\begin{array}{l}\text { Kerusakan subklinis, secara mikroskopis } \\
\text { terlihat oleh apoptosis osteolas baru dan } \\
\text { berkurangnya osteoblas endosteal }\end{array}$ & $\begin{array}{l}\text { Penemuan klinis nonspesifik } \\
\text { dan gejala seperti nyeri rahang } \\
\text { atau osteosklerosis namun } \\
\text { tidak terdapat bukti klinis } \\
\text { adanya paparan tulang }\end{array}$ & \\
\hline Tingkat 1 & $\begin{array}{l}\text { A. Tulang terpapan yang tidak nyeri }<1 \mathrm{~cm} \\
\text { B. Tulang terpapan yang tidak nyeri }>1 \mathrm{~cm}\end{array}$ & $\begin{array}{l}\text { Terpaparnya/ tulang nekrotik } \\
\text { pada pasien asimptomatis dan } \\
\text { tidak memiliki gejala infeksi }\end{array}$ & $\begin{array}{l}\text { BRONJ Fokus : tanda klinis menunjukan tulang } \\
\text { terekspos, kegoyangan gigi tiba- tiba, soket post- } \\
\text { ekstraksi yang tidak sembuh, fistula mukosa, } \\
\text { pembengkakan, pembentukan abses, trismus, } \\
\text { deformitas mandibula, dan atau hipostesi/ } \\
\text { pasrestesi pada bibir. } \\
\text { Penemuan secara CT: peningkatan densitas tulang } \\
\text { terbatas pada regio alveolar tulang (penebalan } \\
\text { trabekular dan atau osteosklerosis fokal), dengan } \\
\text { atau tanpa gejala: penembalan yang terlihat dan } \\
\text { lamina dura sklerotik, soket alveolar yang } \\
\text { tertinggal, dan atau hancurnya tulang kurtikal } \\
\text { 1a. Asimptomatik } \\
\text { 1b. Simptomatik (terdapat nyeri dan purulen) }\end{array}$ \\
\hline Tingkat 2 & $\begin{array}{l}\text { A. Tulang terpapar tunggal yang terinfeksi dan } \\
\text { nyeri }<2 \mathrm{~cm}\end{array}$ & $\begin{array}{l}\text { Terpaparnya/ tulang nekrotik } \\
\text { yang berhubungan dengan }\end{array}$ & $\begin{array}{l}\text { BRONJ Difus : tanda klinis dan gejala serupa dengan } \\
\text { tingkat } 1\end{array}$ \\
\hline & $\begin{array}{l}\text { B. Tulang terpapar tunggal yang terinfeksi dan } \\
\text { nyeri }>2 \mathrm{~cm}\end{array}$ & $\begin{array}{l}\text { infeksi yang terlihat dari nyeri } \\
\text { dan eritema di regio pada } \\
\text { tulang yang terpapar dengan } \\
\text { atau tanpa adanya purulen }\end{array}$ & $\begin{array}{l}\text { Penemuan secara CT: peningkatan densitas tulang } \\
\text { basal (osteosklerosis difus), dengan atau tanpa } \\
\text { tanda: prominensia nevus saraf alveolar inferior; } \\
\text { reaksi periosteal, sinusitis, pembentukan } \\
\text { sequestra, dan atau fistula oroantral } \\
\text { 1a. Asimptomatik } \\
\text { 1b. Simptomatik (terdapat nyeri dan purulen) }\end{array}$ \\
\hline Tingkat 3 & $\begin{array}{l}\text { A. Terpaparnya area tulang secara multipel } \\
\text { tanpa temuan klinis osteolisis, fistula } \\
\text { orocutaneus, atau fraktur patologis } \\
\text { B. Terpaparnya tulang }>3 \mathrm{~cm} \text { atau dengan } \\
\text { penemuan klinis adanya osteolisis, atau } \\
\text { fistula orocutaneus, atau fraktur patologis }\end{array}$ & $\begin{array}{l}\text { Terpapar/ tulang nekrotik pada } \\
\text { pasien dengan nyeri, infeksi, } \\
\text { serta satu atau lebih gejala sbb: } \\
\text { fraktur patologis, fistula } \\
\text { ekstraoral, atau pelebaran } \\
\text { osteolisis ke batas inferior atau } \\
\text { dasar sinus }\end{array}$ & $\begin{array}{l}\text { BRONJ Rumit : menyerupai tingkat } 2 \text { dengan satu } \\
\text { atau lebih gejala. Tanda klinis dan gejala : fistula } \\
\text { ekstraoral, mandibular stumps yang tidak pada } \\
\text { tempatnya, kebocoran cairan nasal. } \\
\text { Penemuan secara CT : osteosklerosis tulang yang } \\
\text { berdekatan (zigoma, palatum keras), fraktur } \\
\text { mandibula patologis, dan atau osteolisis yang } \\
\text { menyebar ke dasar sinus }\end{array}$ \\
\hline
\end{tabular}

\section{Pencegahan MRONJ}

Pemeriksaan gigi dan perawatan yang memadai sangat penting untuk mengurangi risiko ONJ pada pasien yang menggunakan terapi antiresorpsi atau antiangiogenik atau sebelum memulai pemberian BP pada perawatan MRONJ umumnya sulit, dan strategi terapi yang optimal masih dalam proses evaluasi penelitian selanjutnya. Oleh karena itu, pencegahan lebih penting dibandingkan pengobatan MRONJ. Beberapa penulis menyarankan "drug holiday" sebelum pencabutan gigi atau prosedur invasif lainnya. ${ }^{8}$

\section{Pasien Kanker yang Akan Memulai Perawatan Medis Intravena}

Sebelum memulai perawatan medis BP intravena, pasien harus selalu dievaluasi dengan cermat oleh dokter gigi. Tujuan utama pencegahan terjadinya MRONJ adalah mempersiapkan gigi dan kavitas oral dalam keadaan sehat (mouth preparation) sebelum terapi BP dengan menghilangkan faktor lokal pada gigi dan kavitas oral yang mungkin menjadi sumber port de entry masuknya mikroorganisme dengan melakukan perawatan pada jaringan keras dan jaringan lunak misalnya perawatan luka pada mukosa oral, pembersihan karang gigi, penambalan dan perawatan endodontik gigi, ekstraksi gigi yang menjadi fokus infeksi, pembuatan gigi tiruan, sehingga gigi dan kavitas oral dalam keadaan intak dan sehat. Pasien harus memiliki kebersihan mulut yang baik dan diedukasi untuk melaporkan segala kelainan, peradangan, atau paparan tulang yang terjadi, sehingga pasien 
dilibatkan dalam tindak lanjut klinis-radiologis berkala. ${ }^{9}$

\section{Pasien Kanker Asimptomatik yang Menjalani Perawatan Medis Intravena}

Sangat penting akan adanya evaluasi rongga mulut yang terperinci dengan pemeriksaan rutin setiap 4-6 bulan untuk tulang yang terpapar dan diagnosis MRONJ "tahap awal". Ortopantomografi setiap 6-12 bulan untuk bukti radiografi osteosclerosis atau osteolisis, pelebaran ruang ligamen periodontal, atau keterlibatan furkasi harus dibuat. Kebersihan mulut yang baik sangat penting untuk mencegah infeksi gigi yang mungkin memerlukan pembedahan dentoalveolar.Setiap prosedur invasif yang melibatkan cedera tulang memang harus dihindari.Gigi yang tidak dapat direstorasi harus dirawat dengan pembuangan mahkota dan perawatan endodontik dari akar yang tersisa.Gigi dengan kegoyangan kelas 12 harus di-splint dan dicabut hanya jika terdapat lesi gigi/periodontal; pencabutan gigi dengan kegoyangan kelas 3 dan/atau lesi endodontik-periodontal harus dilakukan dengan cedera tulang yang sangat sedikit dan diberikan perawatan antibiotik. Diperlukan profilaksis antibiotik untuk prosedur bedah dan Penisilin menjadi pilihan pertama, dalam kasus alergi penisilin, kombinasi Quinolon-Metronidazol atau Erithromycin-Metronidazole bisa menjadi alternatif. Gigi tiruan yang tidak memadai harus dimodifikasi agar mendapatkan adaptasi, retensi, stabilisasi yang mendukung kesehatan jaringan lunak dan keras. Penempatan implan gigi harus dihindari. ${ }^{10}$

\section{Pasien Osteoporosis yang Akan Memulai Pengobatan secara Oral}

Tahap awal terapi, pasien harus diinstruksikan untuk mengetahui risiko terjadinya MRONJ, terutama jika perawatannya melebihi 4 tahun.Edukasi tentang pengetahuan MRONJ saat ini serta instruksi untuk segera melaporkan setiap adanya tanda dan gejala harus diberikan kepada pasien. Direkomendasikan juga untuk dilakukan tindak lanjut klinis-radiologis.Pentingnya kebersihan mulut dan kesehatan gigi harus diperhatikan. Penempatan implan mungkin dapat dilakukan, tetapi harus dilakukan dengan hati-hati. Dengan terbatasnya data yang ada, maka informed consent untuk risiko yang tidak dapat diverifikasi untuk pengembangan jangka panjang MRONJ perlu dituliskan. ${ }^{11}$

\section{Pasien Osteoporosis yang Menjalani Pengobatan Secara Oral}

Risiko perkembangan MRONJ terkait dengan BP ecara oral sangat rendah, dan meningkat ketika durasi terapi melebihi 4 tahun. Periode ini harus dikurangi dalam kasus komorbiditas serta obat antiangiogenik atau obat kortikosteroid kronis, namun, risiko MRONJ pada pasien yang diobati dengan BP secara oral lebih rendahdibandingkan dengan subyek yang diobati dengan obat IV. Operasi dentoalveolar elektif tidak kontraindikasi pada pasien ini. ${ }^{12}$

\section{Pengobatan MRONJ}

Pendekatan tim multidisiplin sangat disarankan, termasuk dokter gigi, ahli onkologi, dan ahli bedah maksilofasial untuk mengevaluasi dan memutuskan terapi terbaik untuk pasien. Pilihan antara perawatan konservatif dan pembedahan tidaklah mudah, dan harus dibuat berdasarkan kasus per kasus, namun, rencana awal harus sekonservatif mungkin. Tujuan paling penting dari perawatan untuk pasien dengan MRONJ adalah pengendalian infeksi, perkembangan nekrosis tulang, dan rasa nyeri. ${ }^{13}$

\section{Kategori Risiko MRONJ}

Pasien memiliki risiko terjadinya MRONJ jika memiliki riwayat pengobatan dengan 
obat antiresorpsi atau antiangiogenik. Manajemen faktor risiko lokal dan pemeriksaan klinis serta radiologis berkala sangat disarankan. ${ }^{14}$ Tahap Perawatan MRONJ berdasarkan Stadium Klinis adalah sebagai berikut:

i. Tahap 0/ Stadium Klinis 0

Diindikasikan perawatan medis (terapi antiseptik, analgesik, antibiotik, dan antiphlogistic) dan manajemen faktor risiko lokal. Terapi laser tingkat rendah dapat menjadi pilihan yang memungkinkan untuk pengobatan osteonekrosis dengan membantu proses reparatif, meningkatkan indeks osteoblastik, dan merangsang pertumbuhan limfatik dan kapiler darah. Diperlukan tindak lanjut yang cermat untuk evolusi ke tahap yang lebih besar.

ii. Tahap 1/ Stadium Klinis 1

Jika terdapat tulang yang terbuka dan nekrotik atau fistula, harus dibilas dengan cairan antiseptik dan ditutup dengan pasta perekat 3 (tiga) kali sehari. Apabila tidak ada tandatanda penyembuhan, setelah 8 (delapan) minggu dapat dilakukan pembedahan debridement.

iii. Tahap 2/ Stadium Klinis 2

Setelah 2 minggu dilakukan terapi medis untuk mengurangi gejala peradangan, debridemen bedah dapat diindikasikan. Hal tersebut harus dilakukan se- konservatif mungkin tetapi juga harus seluas dan sebesar yang diperlukan untuk pengangkatan total tulang yang terpengaruh. Perawatan antibiotik dan antiphlogistik diberikan dan diperlukan pemeriksaan lanjutan.

iv. Tahap 3/ Stadium Klinis 3

Osteotomi marginal atau segmental direkomendasikan untuk kasus yang parah.Pembedahan invasif diindikasikan hanya jika dapat meningkatkan kualitas hidup pasien. Dalam kasus lain atau jika pasien menolak operasi, pendekatan konservatif untuk mengendalikan gejala dan untuk mencegah perkembangan osteonekrosis diberikan. ${ }^{15}$

\section{Simpulan}

Osteonecrosis of the jaw atau Medication-Related Osteonecrosis of the Jaw (MRONJ) adalah destruksi tulang progresif di daerah maksilofasial pasien yang dapat disebabkan oleh agen farmakologis: antiresorpsi (termasuk bifosfonat (BP) dan receptor activator of nuclear factor kappa- (RANK) B ligand inhibitors) dan antiangiogenik lebih dari 8 minggu. Patofisiologi MRONJ adalah iskemik tulang karena efek dari obat antiresorpsi, antiangiogenesis, dan antivaskularisasi. Komplikasi MRONJ adalah osteonekrosis menjadi port de entry, fokus infeksi, dan sumber nyeri. Tujuan pencegahan MRONJ adalah mencegah komplikasi destruksi tulang; tujuan terapi MRONJ adalah mempromosi sintesis kolagen, angiogenesis, dan epitelisasi. Sebagai dokter gigi dan ahli bedah mulut dan maksilofasial harus meningkatkan edukasi dan penatalaksanaan kesehatan gigi dan kavitas oral agar mencegah komplikasi osteonekrosis rahang yang lebih luas.

\section{Daftar Pustaka}

1. Ruggiero SL, Dodson TB, Fantasia J, Goodday R, Aghaloo T, Mehrotra B, et al. American Association of oral and maxillofacial surgeons position paper on medication-related osteonecrosis of the jaw - 2014 update. J Oral Maxillofac Surg. 2014;72:1938-56. [PubMed: 25234529]

2. Ruggiero SL, Dodson TB, Assael LA, Landesberg R, Marx RE, Mehrotra B. American Association of oral and maxillofacial surgeons position paper on bisphosphonate- 
related osteonecrosis of the jaws - 2009 update. J Oral Maxillofac Surg. 2009;67(5 Suppl):2-12. [PubMed: 19371809]

3. Rosella D, Papi P, Giordino R, Cicalini E, Picolli L, Pompa G. 2016. Medicationrelated Osteonecrosis of The Jaw: Clinical and Practical Guidelines. J int Soc Prev Community Dent; 6(2): 97-104.

4. Allen MR, Burr DB. The pathogenesis of bisphosphonate-related osteonecrosis of the jaw: So many hypotheses, so few data. J Oral Maxillofac Surg. 2009;67(5 Suppl):6170. [PubMed: 19371816]

5. Yamashita J, McCaulaey L, Poznak CV. Updates on Osteonecrosis of The Jaw. 2011. Curr OPin Support Palliant Care. Author manuscript; available in PMC.

6. Khan AA, et al. Diagnosis and Management of Osteonecrosis of The Jaw: a Systematic Review and International Consensus. 2015. J of Bone and Mineral Research; vol 30 No.1; pp 3-23.

7. Berenson JR, Hillner BE, Kyle RA, Anderson K, Lipton A, Yee GC, et al. American society of clinical oncology clinical practice guidelines: The role of bisphosphonates in multiple myeloma. J Clin Oncol. 2002;20:3719-36. [PubMed: 12202673]

8. Fede OD et al. The Dental Management of Patients at Risk of Medication Related Osteonecrosis of the Jaw: New Paradigm of Primary Prevention. Biomed Research International. 2018; article ID 2684924.

9. Kumar V. Biphosphonate Related Osteonecrosis of The Jaw: an Update. 2014. J Maxillo Fac Oral Surg: 13(4): 386-393.

10. Riberio GH, et al. Osteonecrosis of the Jaw: a Review and Update in Etiology and Treatment. 2017. Braz J Otorhinolaryngol.

11. Delmas PD. Clinical potential of RANKL inhibition for the management of postmenopausal osteoporosis and other metabolic bone diseases.J Clin Densitom. 2008;11:325-38. [PubMed: 18375161]

12. Rugani P, Acham S, Kirnbauer B, Truschnegg A, Obermayer-Pietsch B, Jakse N. Stage-related treatment concept of medication-related osteonecrosis of the jaw-a case series. Clin Oral Investig.2015;19:1329-38. [PubMed: 25511385]

13. Carlson ER, Basile JD. The role of surgical resection in the management of bisphosphonate-related osteonecrosis of the jaws. J Oral Maxillofac Surg. 2009;67(5 Suppl):85-95. [PubMed: 19371819]

14. Seth R, Futran ND, Alam DS, Knott PD. Outcomes of vascularized bone graft reconstruction of the mandible in bisphosphonate-related osteonecrosis of the jaws.Laryngoscope. 2010;120:2165-71. [PubMed: 20824743]

15. Pompa G, Bignozzi I, Cristalli MP, Quaranta A, Di Carlo S. Bisphosphonates and Osteonecrosis of the jaw: The oral surgeon's perspective. Eur $\mathrm{J}$ Inflamm. 2012;101:11-23. 